\title{
PENGARUH KUALITAS PELAYANAN DAN FASILITAS TERHADAP KEPUASAN NASABAH DI PT BANK CENTRAL ASIA TBK KCU KELAPA GADING JAKARTA UTARA
}

\author{
Alfonsus B. Say. \\ STIE Unisadhuguna Jakarta Indonesia \\ Email: alfons.bsay@ubs-usg.ac.id
}

\begin{abstract}
Abstrak
Pendahuluan: Saat ini kepuasan nasabah menjadi fokus perhatian oleh hampir semua pihak, baik pemerintah, pelaku bisnis, konsumen dan sebagainya. Hal ini disebabkan semakin baiknya pemahaman mereka atas konsep kepuasan nasabah sebagai strategi untuk memenangkan persaingan di dunia bisnis. Kepuasan nasabah merupakan hal yang penting bagi penyelenggara jasa.

Tujuan: Penelitian ini bertujuan untuk mengetahui apakah ada pengaruh kualitas pelayanan dan fasilitas terhadap kepuasan nasabah pada PT Bank Central Asia Tbk KCU Kelapa Gading Jakarta Utara. Penelitian ini dilakukan pada bulan Januari 2021 melalui bantuan google form (kuesioner online). Populasi dalam penelitian ini adalah konsumen Bank CentralAsia cabang KCU Kelapa Gading Jakarta Utara. Pengambilan sampel menggunakan teknik non-probability sampling. Sampel yang digunakan dalam penelitian ini adalah sampel jenuh. Seluruh populasi sebanyak 100 orang diambil sebagai sampel dalam penelitian ini.

Metode: Metode pengujian instrumen yang digunakan adalah uji validitas dan uji reliabilitas. Teknik analisis data yang digunakan adalah teknik deskriptif kuantitatif, analisis regresi linier berganda, uji t, uji f.

Hasil: Hasil penelitian menunjukkan bahwa terdapat pengaruh kualitas pelayanan dan fasilitas terhadap kepuasan pelanggan.

Kesimpulan: Berdasarkan hasil penelitian maka diperoleh kesimpulan bahwa variabel kualitas layanan memengaruhi kepuasan nasabah PT Bank Central Asia Tbk KCU Kelapa Gading Jakarta Utara. Hal ini ditunjukkan melalui nilai t hitung variable fasilitas yaitu sebesar 5,809 lebih besar dari t table 1,984. Variabel Fasilitas memengaruhi kepuasan nasabah PT Bank Central Asia Tbk KCU Kelapa Gading Jakarta Utara. Hal ini ditunjukkan melalui nilai t hitung variable layanan yaitu sebesar 3,511 lebih besar dari t table 1,984. Variabel kualitas pelayanan dan fasilitas secara simultan memengaruhi kepuasan nasabah PT Bank Central Asia Tbk KCU Kelapa Gading Jakarta Utara. Dengan nilai sig 0,000<0,050 dan nilai F hitung 58,566 > 3,09 F tabel.
\end{abstract}

Kata Kunci: Kompensasi; Pengembangan Karir; Kinerja Karyawan.

\section{Abstract}

Introduction: Currently, customer satisfaction is the focus of attention by almost all parties, both the government, business people, consumers and so on. This is due to their better understanding of the concept of customer satisfaction as a strategy to win the competition in the business world. Customer satisfaction is important for service providers.

Objective: This study aims to find out whether there is an influence of service quality and facilities on customer satisfaction at PT Bank Central Asia Tbk KCU Kelapa 
Gading North Jakarta. This study was conducted in January 2021 through the help of Google Form (Online Questionnaire). Inner population This research is a consumer of the KCU Kelapa Gading KCU branch of North Jakarta. Sampling using non-probability sampling technique. The sample used in this study is saturated sample. All populations of 100 people were taken as samples in this study.

Method: Method testing instrument that is used is test validity and test reliability. Technique analysis data which used is technique descriptive quantitative regressive analytical, linear test $t$, test $f$.

Result: Results research shows that there is influence quality service and facilities on satisfaction customers.

Conclusion: Based on the results of the study, it can be concluded that the service quality variable affects customer satisfaction at PT Bank Central Asia Tbk KCU Kelapa Gading, North Jakarta. This is indicated by the t-value of the facility variable, which is 5.809, which is greater than the t-table of 1.984. Facility variable affects customer satisfaction of PT Bank Central Asia Tbk KCU Kelapa Gading North Jakarta. This is indicated by the t-value of the service variable, which is 3.511, which is greater than the t-table of 1.984. Variables of service quality and facilities simultaneously affect customer satisfaction of PT Bank Central Asia Tbk KCU Kelapa Gading North Jakarta. With a sig value of $0.000<0.050$ and a calculated $F$ value of $58.566>3.09 \mathrm{~F}$ table.

Key words: Compensation, Development of Career, Performance Employees

\section{Pendahuluan}

Saat ini kepuasan nasabah menjadi fokus perhatian oleh hampir semua pihak, baik pemerintah, pelaku bisnis, konsumen dan sebagainya (Andriansyah, 2015). Hal ini disebabkan semakin baiknya pemahaman mereka atas konsep kepuasan nasabah sebagai strategi untuk memenangkan persaingan di dunia bisnis (Hariadji, 2018). Kepuasan nasabah merupakan hal yang penting bagi penyelenggara jasa, karena nasabah akan menyebarluaskan rasa puasnya kepada calon nasabah, sehingga akan menaikkan reputasi pemberi jasa (Atmaja, 2018).

BCA Prioritas adalah keanggotaaan eksklusif dan prestisius yang diperuntukan untuk nasabah terpilih yang memperoleh undangannya dari BCA. Nasabah prioritas ini memiliki "kelas" berbeda dengan nasabah biasa. Salah satu syarat yang perlu dipenuhi untuk menjadi nasabah prioritas adalah memiliki saldo mengendap selama satu tahun terakhir minimal Rp 500 juta yang terdapat di tabungan/giro, deposito, investasi atau gabungan dari semuanya.

Secara umum Bank harus menerapkan strategi bisnis kombinasi antara strategi ofensif dan defensif (Evani, 2019). Dimana strategi ofensif perlu ditujukan untuk meraih atau memperoleh nasabah baru, sedangkan untuk meningkatkan pangsa pasar dan strategi defensif berusaha untuk mengurangi kemungkinan customer exit dan beralihnya konsumen dari perusahaan (Wibowo, 2017).

Kepuasan konsumen dipengaruhi dua variabel utama, yaitu Expectations dan Perceived Performance, bila Perceived Performance melebihi Expectations, maka 
konsumen mendapatkan kepuasan (Bhaskara, Mandey, \& Nelwan, 2014), akhirnya akan menciptakan loyalitas konsumen (Bhaskara et al., 2014). Menurut (Shofiana, Widyatmaja, \& Sari, 2019) ada beberapa faktor yang menentukan kualitas jasa, yaitu: 1.Tangibles (berwujud) yaitu bukti fisik dari jasa, bisa berupa fasilitas fisik, peralatan yang digunakan, representasi fisik dari jasa. 2. Empathy (empati) meliputi kemudahan dalam hal melakukan hubungan komunikasi yang baik, perhatihan pribadi dan memahami kebutuhan pelanggan 3.Reliability (kehandalan) kemampuan memenuhi janji layanan secara cepat, akurat dan memuaskan. 4. Responsifines (ketanggapan) merupakan keingginan para staf untuk membantu para pelanggan dan member pelayanana dengan tanggap. 5. Assurance (Jaminan) Mencakup pengetahuan, kemampuan, kesopanan dan keragu - raguan.

Hal yang perlu diperhatikan dalam memberikan pelayanan adalah mendengar suara nasabah (Indonesia, 2014), hal ini berarti Bank harus melakukan interaksi dengan nasabah dengan maksud untuk memperoleh umpan balik (feed back) berapa tanggapan nasabah tentang sarana dan prasarana yang berhubungan dengan pelayanan yang diberikan sebagai kontrol dan ukuran keberhasilan.

\section{Metode Penelitian}

Metode yang digunakan di dalam penelitian ini adalah metode deskriptif kuantitatif (Unaradjan, 2019). Metode kuantitatif adalah ilmu yang berkaitan dengan tata cara (metode) pengumpulan data, analisa data, dan interpretasi hasil analisis untuk mendapatkan informasi guna penarikan kesimpulan dan pengambilan keputusan (Prabowo, 2018). Penelitian ini akan melakukan survey dengan menggunakan alat kuisioner sebagai instrumen pengumpulan data dan hasil itulah akan diolah dengan software SPSS (Ghozali, 2018).

Populasi pada penelitian ini merupakan nasabah Prioritas pada PT Bank Central Asia Tbk KCU Kelapa Gading Jakarta Utara sebanyak 100 orang. Menurut (Kania Sabariah, 2013) Teknik sampling yang digunakan adalah Non Probality Sampling yaitu teknik pengambilan sampel yang tidak memberi peluang/kesempatan yang sama bagi setiap unsur atau anggota populasi untuk dipilih menjadi sampel. Teknik sampling yang digunakan dalam penelitian ini adalah sampel jenuh atau sering disebut juga sensus. Jumlah populasi sebesar 100 orang itu diambil semua sebagai sampel dalam penelitian ini (Indra, Iskandar, \& Faruk, 2019).

Teknik pengumpulan data yang digunakan dalam penelitian ini dibagi menjadi tiga bagian, yaitu:

a. Kuesioner

Kuesioner adalah teknik pengumpulan data yang dilakukan dengan cara memberi seperangkat pertanyaan atau pernyataan tertulis kepada responden untuk dijawabnya. Kuesioner disebarkan dalam bentuk angket menggunakan skala likert

b. Wawancara

Wawancara adalah metode pengumpulan data dengan melakukan tanya jawab secara lisan kepada pihak yang bersangkutan dengan penelitian ini. 


\section{c. Dokumentasi}

Menurut (Sugiyono., 2017) dokumentasi merupakan catatan peristiwa pada waktu yang lalu, dan dapat berbentuk tulisan, gambar, maupun karya - karya monumental dari seseorang.

\section{Hasil dan Pembahasan}

\section{A. Uji Validitas}

Uji validitas digunakan untuk mengetahui valid atau tidaknya item-item kuesioner yang diuji. Dengan kriterian pengukuran, apabila rhitung $\geq$ rtabel maka dapat dikatakan item kuesioner tersebut valid.

Tabel.1. Uji Validitas Kualitas Pelayanan

\begin{tabular}{cccc}
\hline Butir & R Hitung & R Tabel & Ket \\
\hline 1 & 0.7116 & 0,1966 & Valid \\
\hline 2 & 0.5801 & 0,1966 & Valid \\
\hline 3 & 0.5930 & 0,1966 & Valid \\
\hline 4 & 0.6891 & 0,1966 & Valid \\
\hline 5 & 0,6790 & 0,1966 & Valid \\
\hline 6 & 0,6630 & 0,1966 & Valid \\
\hline 7 & 0,7096 & 0,1966 & Valid \\
\hline 8 & 0,7704 & 0,1966 & Valid \\
\hline 9 & 0,6693 & 0,1966 & Valid \\
\hline 10 & 0,6503 & 0,1966 & Valid \\
\hline \multicolumn{4}{c}{ Sumber: Hasil Olah data SPSS (2021) }
\end{tabular}

Berdasarkan hasil pengelolahan data pada Table 1 tersebut di atas, seluruh butir instrument dinyatakan valid, hal tersebut dapat dibuktikan dari $r$ hitung yang lebih besar dari $r$ table.

Tabel.2. Uji Validitas Fasilitas

\begin{tabular}{cccc}
\hline Butir & R Hitung & R Tabel & Ket \\
\hline 1 & 0,6875 & 0,1966 & Valid \\
\hline 2 & 0,7173 & 0,1966 & Valid \\
\hline 3 & 0,7409 & 0,1966 & Valid \\
\hline 4 & 0,7682 & 0,1966 & Valid \\
\hline 5 & 0,5852 & 0,1966 & Valid \\
\hline 6 & 0,5885 & 0,1966 & Valid \\
\hline 7 & 0,6309 & 0,1966 & Valid \\
\hline
\end{tabular}

Sumber: Hasil Olah data SPSS (2021)

Berdasarkan hasil pengelolahan data pada Table 2 di atas, seluruh butir instrument dinyatakan valid, hal tersebut dapat dibuktikan dari $r$ hitung yang lebih besar dari $r$ table.

Tabel.3. Uji Validitas Kepuasan Nasabah

\begin{tabular}{cccc}
\hline Butir & R Hitung & R Tabel & Ket \\
\hline 1 & 0,7285 & 0,1966 & Valid \\
\hline 2 & 0,7178 & 0,1966 & Valid \\
\hline 3 & 0,7027 & 0,1966 & Valid \\
\hline
\end{tabular}




\begin{tabular}{cccc}
\hline 4 & 0,7466 & 0,1966 & Valid \\
\hline 5 & 0,7077 & 0,1966 & Valid \\
\hline 6 & 0,7786 & 0,1966 & Valid \\
\hline 7 & 0,5809 & 0,1966 & Valid \\
\hline 8 & 0,6408 & 0,1966 & Valid \\
\hline
\end{tabular}

Sumber: Hasil Olah data SPSS (2021)

Berdasarkan hasil pengelolahan data pada Tabel 3 tersebut, seluruh butir instrument dinyatakan valid, hal tersebut dapat dibuktikan dari $r$ hitung yang lebih besar dari $r$ table.

\section{B. Uji Reliabilitas}

Setelah semua variable penelitian dinyatakan valid, maka pengujian berikutnya adalah ujia reliabiltas (Yunus, 2012). Tujuan pengujian ini adalah menilai kestabilan ukuran dan konsistensi responden dalam menjawab kuisioner. Jika nilai Cronbach Alpha lebih besar dari 0,6 maka kuisioner dapat dikatakan memenuhi konsep reliabilitas. Sedangkan, jika nilai Cronbach Alpha lebih kecil dari 0,6 maka dapat dikatakan kuisioner tidak memenuhi konsep reliabilitas, sehingga pernyataan tidak dapat dijadikan sebagai alat ukur penelitian.

Tabel.4. Uji Reliabiltas Kualitas Pelayanan

\begin{tabular}{cc}
\hline $\begin{array}{c}\text { Cronbach's } \\
\text { Alpha }\end{array}$ & $\begin{array}{c}\mathrm{N} \text { of } \\
\text { Items }\end{array}$ \\
\hline .916 & 10 \\
\hline
\end{tabular}

Sumber: Hasil Olah data SPSS (2021)

Berdasarkan table diatas, untuk uji reliabilitas variable kualitas pelayanan (X1) dengan nilai Cronbach's Alpha sebesar 0,916 maka dapat disimpulkan instrument penelitian mengenai variable Kualitas Pelayanan (X1) adalah Reliabel karena 0,916 $>0,6$.

\begin{tabular}{cc}
\multicolumn{2}{c}{ Tabel.5. Uji Reliabiltas Fasilitas } \\
\hline $\begin{array}{c}\text { Cronbach's } \\
\text { Alpha }\end{array}$ & $\mathrm{N}$ of \\
Items \\
\hline .843 & 7 \\
\hline
\end{tabular}

Sumber: Hasil Olah data SPSS (2021)

Berdasarkan table diatas, untuk uji reliabilitas variable fasilitas (X2) dengan nilai Cronbach's Alpha sebesar 0,843 maka dapat disimpulkan instrument penelitian mengenai variable Fasilitas (X2) adalah Reliabel karena 0,843 > 0,6.

\section{Uji Asumsi Klasik}

\section{Uji Normalitas}

Uji Normalitas dilakukan untuk mengetahui suatu data berkontribusi normal atau tidak. Adapun hasil uji normalitas dengan metode Kolmogorov-Smirnov dapat dilihat pada Tabel 7 berikut:

Tabel 6. Uji Normalitas dengan Kplmogorov-Smirnov Test

\begin{tabular}{cc}
\hline & $\begin{array}{c}\text { Unstandardized } \\
\text { Residual }\end{array}$ \\
\hline $\mathrm{N}$ & 100 \\
\hline
\end{tabular}




\begin{tabular}{|c|c|c|}
\hline \multirow[t]{2}{*}{ Normal Parameters $^{\mathrm{a} b}$} & Mean & .0000000 \\
\hline & Std. Deviation & 2.52718220 \\
\hline \multirow[t]{3}{*}{ Most Extreme Differences } & Absolute & .088 \\
\hline & Positive & .057 \\
\hline & Negative & -.088 \\
\hline Test statistic & & 0.88 \\
\hline Asymp. Sig. (2-Tailed) & & $.55^{\mathrm{c}}$ \\
\hline \multicolumn{3}{|c|}{ a. Test Distribution is Normal } \\
\hline \multicolumn{3}{|l|}{ b. Calculated From data } \\
\hline c. Liliefors Significance & Correction & \\
\hline
\end{tabular}

Sumber: Hasil Olah data SPSS (2021)

Berdasarkan tabel di atas, nilai signifikansi (2- tailed) sebesar 0.055, dapat diartikan bahwa nilai signifikansi (2-tailed) alat ukur tersebut berada di atas 0.05 sehingga data dikatakan bahwa model regresi telah memenuhi asumsi kenormalan.

\section{Uji Multikolinieritas}

Uji Multikolenieritas ini dilakukan bertujuan untuk menguji apakah model regresi ditemukan adanya kolerasi antar variabel bebas (independen). Model regresi yang baik seharusnya tidak terjadi korelasi diantara variabel independen. Model regresi yang baik yaitu ketika tidak terdapat multikolinieritas dalam pengujiannya. Pedoman suatu model regresi yang bebas dari multikolinieritas yaitu memiliki VIF $<10$ dan angka tolerance $>0,1$.

Tabel 7. Uji Multikolenieritas

\begin{tabular}{cccccccc}
\hline Model & \multicolumn{2}{c}{$\begin{array}{c}\text { Unstandardized } \\
\text { Coefficient }\end{array}$} & $\begin{array}{c}\text { Standardized } \\
\text { Coefficient }\end{array}$ & $\mathrm{t}$ & Sig & \multicolumn{2}{c}{ Collinearity statiscics } \\
\cline { 2 - 3 } \cline { 6 - 8 } & $\mathrm{B}$ & Std. Error & & & & Tolerance & VIF \\
\hline (Constant) & 1.798 & 3.138 & & .573 & .568 & & \\
\hline Kualitas & .473 & .081 & .508 & 5.809 & .000 & .611 & 1.638 \\
\hline Fasilitas & .405 & .115 & .307 & 3.511 & .001 & .611 & 1.638 \\
\hline
\end{tabular}

Sumber: Hasil Olah data SPSS (2021)

Berdasarkan Tabel 7 di atas, untuk uji multikolinieritas nilai tolerance > 0,10 yaitu 0,611 dan nilai VIF tidak melebihi 10 , yaitu 1,638 maka dapat dikatakan bahwa tidak terjadi multikolinieritas.

\section{Uji Heterokedastisitas}

Uji Heteroskedastisitas adalah uji yang dilakukan dengan bertujuan untuk menguji apakah dalam model regresi terjadi ketidaksamaan variance dari residual satu pengamatan ke pengamatan lain. Jika variance dari residual satu pengamatan ke pengamatan lain berbeda maka disebut heteroskedastisitas.

Tabel 8. Uji Heteroskedastisitas Menggunakan Metode Glejser

$$
\text { Coefficients }
$$

\begin{tabular}{|c|c|c|c|c|}
\hline \multirow[t]{2}{*}{ Model } & Unstandardized coefficients & Standardized coefficients & \multirow[t]{2}{*}{$\mathrm{t}$} & \multirow[t]{2}{*}{ Sig } \\
\hline & Std. Error & Beta & & \\
\hline
\end{tabular}




\begin{tabular}{llcccc}
\hline Constant & 6.811 & 2.799 & & 2.434 & .017 \\
\hline Kualitas & -.039 & 0.73 & -.067 & -.531 & .597 \\
\hline Fasilitas & -.156 & .103 & -.191 & -1.514 & .133 \\
\hline
\end{tabular}

a. Dependent Variabel : LN_RES

Sumber: Hasil Olah data SPSS (2021)

Berdasarkan Tabel 8 di atas untuk uji heterokedastisitas hasil pengujian Glejser pada tabel Coefficients menunjukan nilai signifikansi pada X1 dan X2 > 0,05, maka dapat dikatakan bahwa tidak terjadi heteroskedastisitas.

\section{Analisis Regresi Linier Berganda}

Dari table 8 didapat bahwa persamaan regresi linear berganda:

$$
\mathrm{Y}=\mathbf{6 . 8 1 1}+\mathbf{- 0 , 0 3 9 X 1 + 0 , 1 5 6 \times 2 + e}
$$

Dapat dijelaskan sebagai berikut:

a. Nilai koefisien intersep sebesar 6.811 menyatakan bahwa jika variabel Kualitas Pelayanan (X1), variabel Fasilitas (X2) nol, maka nilai variabel Kualitas Nasabah (Y) adalah 6.811.

b. Nilai koefisien regresi variable Kualitas Pelayanan (X1) -0,039 terhadap variable Kepuasan Nasabah (Y) sebesar 6,811, hal ini berarti jika variabel Kualitas Pelayanan (X1) naik satu satuan maka akan menurunkan variabel Kepuasan Nasabah (Y) sebesar -0.039, dengan asumsi variabel lainnya tetap.

c. Nilai koefisien regresi variabel Fasiltas (X2) 0,653 terhadap variabel Kepuasan Nasabah (Y) adalah sebesar 0.653. Hal ini berarti jika variabel Fasilitas (X2) naik satu satuan akan meningkatkan variabel Kepuasan Nasabah (Y) sebesar 0.653 , dengan asumsi variabel lainnya tetap.

\section{Uji t}

a. Hasil pengujian hipotesis pertama (H1): Diketahui nilai sig untuk pengaruh X1 terhadap Y sebesar $0,000<0,050$ dan nilai t hitung 5,809 > t table 1,984, sehingga dapat disimpulkan bahwa $\mathrm{H} 1$ diterima yang berarti terdapat pengaruh X1 terhadap Y.

b. Hasil pengujian hipotesis kedua $(\mathrm{H} 2)$ : Diketahui nilai sig untuk pengaruh $\mathrm{X} 2$ terhadap $\mathrm{Y}$ sebesar $0,001<0,050$ dan nilai $\mathrm{t}$ hitung 3,511> t table 1,984, sehingga dapat disimpulkan bahwa $\mathrm{H} 2$ diterima yang berarti terdapat pengaruh X2 terhadap Y.

\section{Uji F}

Tabel 9. Uji F

\begin{tabular}{cccccc}
\hline Model & Sum of squares & Df & Mean Square & F & Sig \\
\hline Regression & 763.512 & 2 & 381.756 & 58.566 & $.000^{\mathrm{b}}$ \\
\hline Residual & 632.278 & 97 & 6.518 & & \\
\hline Total & 1395.790 & 99 & & & \\
\hline a. & Dependent Variable : Kepuasan Nasabah & & \\
\hline b. & Predictors : (constant) kualitas layanan, fasilitas & \\
\hline
\end{tabular}

Sumber: Hasil Olah data SPSS (2021) 
Hasil pengujian Hipotesis ketiga (H3) Berdasarkan output diatas diketahui nilai sig untuk pengaruh $\mathrm{X} 1$ dan $\mathrm{X} 2$ secara simultan terhadap $\mathrm{Y}$ adalah sebesar $0,000<0,050$ dan nilai $\mathrm{F}$ hitung $58.566>3,09 \mathrm{~F}$ table, sehingga dapat disimpulkan bahwa H3 diterima yang berarti terdapat pengaruh X1 dan X2 secara simultan terhadap Y.

\section{Koefisien Determinasi}

Tabel 10. Koefisien Determinasi

\begin{tabular}{ccccc}
\hline Model & $\mathrm{R}$ & $\mathrm{R}$ Square & Adjusted R square & Std. Error of The Estimate \\
\hline 1 & $.700^{\mathrm{a}}$ & .489 & .484 & 2.697 \\
\hline
\end{tabular}

a. Predictors : (Constant), Kualitas pelayanan, Fasilitas

Sumber: Hasil Olah data SPSS (2021)

Menurut hasil dari table diatas maka didapatkan nilai Adjusted R Square (koefisien determinasi) sebesar 0,484 yang artinya pengaruh variable independen (X) terhadap variable dependen (Y) sebesar 0,489\%.

\section{Kesimpulan}

Berdasarkan hasil penelitian maka diperoleh kesimpulan bahwa variabel kualitas layanan memengaruhi kepuasan nasabah PT Bank Central Asia Tbk KCU Kelapa Gading Jakarta Utara. Hal ini ditunjukkan melalui nilai t hitung variable fasilitas yaitu sebesar 5,809 lebih besar dari t table 1,984. Variabel Fasilitas memengaruhi kepuasan nasabah PT Bank Central Asia Tbk KCU Kelapa Gading Jakarta Utara. Hal ini ditunjukkan melalui nilai t hitung variable layanan yaitu sebesar 3,511 lebih besar dari $\mathrm{t}$ table 1,984. Variabel kualitas pelayanan dan fasilitas secara simultan memengaruhi kepuasan nasabah PT Bank Central Asia Tbk KCU Kelapa Gading Jakarta Utara. Dengan nilai sig 0,000<0,050 dan nilai F hitung 58,566 > 3,09 F tabel. 


\section{DAFTAR PUSTAKA}

Andriansyah, andriansyah. (2015). Pengaruh customer relationship dan keunggulan produk terhadap kepuasan nasabah pada bank tabungan negara (btn) cabang pemuda di surabaya. Universitas wijaya putra.

Atmaja, Jaka. (2018). Kualitas pelayanan dan kepuasan nasabah terhadap loyalitas pada bank BJB. Jurnal Ecodemica, 2(1), 49-63.

Bhaskara, Satriyo U. P., Mandey, Silvya L., \& Nelwan, Olivia. (2014). Customer Relationship Management (CRM) Dan Personal Selling Pengaruhnya Terhadap Kepuasan Konsumen Pada Pt Virgo Ekspres Tours \& Travel Manado. Jurnal EMBA: Jurnal Riset Ekonomi, Manajemen, Bisnis Dan Akuntansi, 2(1).

Evani, elisa. (2019). Strategi ofensif partai persatuan indonesia dalam mendapatkan dukungan massa (Studi di DPD Partai Persatuan Indonesia Kabupaten Ponorogo). Universitas Muhammadiyah Ponorogo.

Ghozali, Imam. (2018). Aplikasi analisis multivariate dengan program IBM SPSS 25.

Hariadji, Roekma. (2018). Pengaruh Kualitas Layanan, Kualitas Produk, dan Kepercayaan Nasabah Terhadap LOyalitas Nasabah Melalui Kepuasan Nasabah. JURNAL ILMIAH EKBANK, I(2).

Indonesia, Ikatan Bankir. (2014). Memahami bisnis bank syariah. Gramedia Pustaka Utama.

Indra, Dede, Iskandar, Yusup, \& Faruk, Mujaddid. (2019). Pengaruh Keterlibatan Kerja Dan Kohesivitas Dalam Kelompok Kerja Terhadap Kinerja Karyawan (Suatu Studi pada Lembaga Pemasyarakatan Kelas II-B Ciamis). Business Management and Entrepreneurship Journal, 1(4), 193-205.

Kania Sabariah, Mira. (2013). Teknik Sampling.

Prabowo, Anindita Lakmi. (2018). Pengaruh Kepemimpinan Transformasional dan Motivasi Kerja Terhadap Kinerja Karyawan PT. Media Nusantara Informasi Biro Jawa Timur. JMM17 Jurnal Ilmu Ekonomi Dan Manajemen, 5(02).

Shofiana, Riezcha, Widyatmaja, I. Gusti Ngurah, \& Sari, Ni Putu Ratna. (2019). FaktorFaktor yang Menentukan Keputusan Pembelian Produk dan Jasa di Titik Temu Coffee Seminyak. Jurnal Kepariwisataan Dan Hospitalitas, 3(1), 240-255.

Sugiyono. (2017). Metode Penelitian Kuantitatif Kualitatif \& RND. Bandung: Alfabeta.

Unaradjan, Dominikus Dolet. (2019). Metode penelitian kuantitatif. Penerbit Unika Atma Jaya Jakarta.

Wibowo, Bambang Sri. (2017). Pengaruh Kualitas Layanan dan Citra Merek Terhadap Kepuasan Nasabah Centratama Nasional Bank Surabaya. JPIM (Jurnal Penelitian Ilmu Manajemen), 2(1), 27-Halaman.

Yunus, Eddy. (2012). Pengaruh Kompetensi Sumber Daya Manusia Terhadap Kinerja Pegawai KPPBC Tipe Madya Pabean Tanjung Perak Surabaya. EKUITAS (Jurnal Ekonomi Dan Keuangan), 16(3), 368-387. 